\title{
PENGARUH RASIONALITAS PENGGUNAAN ANTIHIPERTENSI DENGAN STANDART GUIDELINE JNC 8 TERHADAP KEBERHASILAN TERAPI HIPERTENSI DI RS PANTI WALUYO SURAKARTA
}

\section{THE INFLUENCE OF RATIONALITY THE USE OF ANTIHYPERTENSIVE WITH STANDART GUIDELINE JNC 8 TO SUCCESSFUL THERAPY HYPERTENSION IN RS PANTI WALUYO SURAKARTA}

\author{
Truly Dian Anggraini ${ }^{1}$, Eka Wisnu Kusuma², Deswinda Diandari ${ }^{3}$ \\ truly_24hours@yahoo.co.id \\ 1,2,3Program Studi DIII Farmasi,STIKES Nasional, Surakarta
}

\begin{abstract}
Abstrak
Hipertensi merupakan masalah utama kesehatan publik di seluruh dunia dan merupakan faktor resiko penyakit kardiovaskuler tersering. Prevalensi hipertensi pada penduduk umur 18 tahun ke atas sebesar 29,8\%. Data epidemiologi menunjukkan bahwa peningkatan tekanan darah akan meningkatkan kejadian kardiovaskuler, sehingga hipertensi harus diobati dengan tepat. Penelitian ini bertujuan untuk mengetahui pengaruh rasionalitas penggunaan antihipertensi dengan standar guideline JNC 8 terhadap keberhasilan terapi hipertensi di RS Panti Waluyo Surakarta tahun 2016.

Penelitian ini merupakan penelitian cohortdimana pengambilan data dilakukan secara retrospektif dari catatan rekam medik pasien hipertensi rawat inap pada tahun 2016. Setelah diperoleh sampel maka akan dianalisis pola penggunaan antihipertensi serta rasionalitas penggunaan antihipertensi dengan standar guideline JNC 8 dianalisis secara diskriptif, pengaruh rasionalitas penggunaan antihipertensi dengan standar guideline JNC 8 terhadap keberhasilan terapi (dilihat dari tercapainya target tekanan darah pasien) dianalisis secara statistik menggunakan Chi-square.

Hasil penelitian, 84 pasien mendapatkan terapi hipertensi yang rasional sesuai dengan guideline JNC 8 dan 16 pasien mendapatkan terapi hipertensi yang tidak rasional dengan guideline JNC 8. Pola obat antihipertensi, 52 pasien diresepkan obat antihipertensi tunggal, 43 pasien kombinasi 2 obat antihipertensi, selebihnya pasien diresepkan lebih dari 2 antihipertensi. Keberhasilan terapi, 65 pasien dari 84 pasien yang mendapatkan terapi hipertensi yang rasional mampu mencapai target tekanan darah sehingga terapi dikatakan berhasil. Ada hubungan yang signifikan antara rasionalitas terapi hipertensi dengan guideline JNC 8 terhadap ketercapaian keberhasilan terapi $(p<0,05)$.
\end{abstract}

Kata kunci: Hipertensi, Rasionalitas, Keberhasilan Terapi

\begin{abstract}
Hypertension is one of the main problems of public health in the whole world and a factor tersering the risks of cardiovascular diseases. The prevalence of hypertension in the population of 18 years and older age of 29,8\%.An epidemiological data shows that a rise in blood pressure will increase the cardiovascular diseases, must be treated with proper and hypertension. The study aimed to identify the influence of rationality use of antihypertensives to the standard guideline jnc 8 to successful therapy hypertension in the hospital at waluyo surakarta year 2016.

The research is research cohort where over the withdrawal of funds data was undertaken in the manner of a retrospective from the records of record medical exam patients hypertension as an in patient in the year 2016. After the recent retrieval of so sample will be analyzed the usage patterns antihypertensive drug as well as rationality
\end{abstract}


the use of antihypertensive drug with a standard guideline jnc 8 have been analyzed in the manner of a diskriptif, the influence of rationality the use of antihypertensive drug with a standard guideline jnc 8 to successful ( therapy the point of view of achieve the target of the pressure of the blood patients ) have been analyzed is statistically use chi-square.

The results of the study, 84 patients get therapy hypertension that is rational in accordance with guideline jnc 8 and 16 patients get therapy hypertension that is irrational with guideline jnc 8 .The pattern of an antihypertensive drug , 52 patients prescribed an antihypertensive drug only begotten or unique son , 43 patients a combination 2 an antihypertensive drug, this is more than the patients prescribed more than 2 antihypertensive drug.The success of therapy, 65 the patient from 84 cases of patients who get therapy hypertension that is rational managed to reach the target the pressure of the blood and he received treatment therapy assessed as being successful .A significant relation exists between rationality therapy hypertension with guideline jnc 8 against ketercapaian the success of therapy $(p<0,05)$.

Keywords: Hypertension, rationalitysuccesstherapy

\section{Pendahuluan}

Hipertensi adalah suatu kondisi dimana seseorang mengalami peningkatan tekanan darah di atas normal, yaitu tekanan darah sistolik $\geq 140$ $\mathrm{mmHg}$ dan atau tekanan darah diastolik $\geq 90$ mmHg. Hipertensi merupakan masalah utama kesehatan publik di seluruh dunia dan merupakan faktor resiko penyakit kardiovaskuler tersering, serta belum terkontrol optimal di seluruh dunia. Namun, hipertensi dapat dicegah dan penanganan dengan efektif dapat menurunkan resikostroke dan serangan jantung (Leonard dan Pikir, 2014).

Prevalensi hipertensi pada populasi global usia diatas 20 tahun pada tahun 2000 sebesar 26,4\% (1 miliar jiwa); 26\% laki-laki, 26,1\% perempuan. Diperkirakan pada tahun 2025, prevalensi hipertensi meningkat menjadi 60\%. Di negara-negara berkembang, prevalensi hipertensi pada laki-laki $37,4 \%$, pada perempuan 37,2\%. Prevalensi hipertensi di Asia termasuk Cina sebesar 20\%, Korea 22,9\%. Perkiraan pada tahun 2025 terjadi peningkatan prevalensi hipertensi global menjadi 29,2\% (1,56 miliar), hal ini terutama didasarkan pada peningkatan tajam hipertensi di negara yang sedang berkembang (Dorobantu dkk., 2010; Erceg dkk., 2009). Pada tahun 2030, terdapat 23 juta kematian kardiovaskuler dan sekitar 85\% terjadi pada negara penghasilan rendah hingga menengah (Damasceno $\mathrm{dkk}, 2009)$.

Pengobatan hipertensi biasanya ditujukan untuk mencegah morbiditas dan mortalitas akibat hipertensi. Pilihan obat bagi masing-masing penderita hipertensi bergantung pada efek samping metabolik dan subjektif yang ditimbulkan, adanya penyakit lain yang mungkin diperbaiki atau diperburuk untuk antihipertensi yang dipilih, adanya pemberian obat lain yang mungkin berinteraksi dengan antihipertensi yang diberikan. Keamanan pemakaian obat antihipertensi perlu diperhatikan.
Meminimalkan resiko pengobatan dengan meminimalkan masalah ketidakamanan pemberian obat. Tujuannya untuk meningkatkan kualitas hidup pasien dengan resiko minimal. Mekanisme pengamanannnya berupa pemantauan efektifitas dan efek samping obat.

Penggunaan obat yang tidak rasional merupakan masalah global yang dapat mengakibatkan rendahnya derajat kesehatan masyarakat. Berbagai penelitian yang dilakukan baik di negara maju maupun negara bekembang selama beberapa tahun terakhir tentang penggunaan obat yang aman dan efektif menunjukkan bahwa penggunaan obat yang tidak rasional merupakan suatu fenomena global dan hanya sedikit peresepan yang ditulis secara rasional. Secara singkat pemberian obat yang rasional sangat penting untuk meningkatkan keberhasilan terapi, namun penelitian sebelumnya yang dilakukan di Rumah Sakit Dr. Kandau Manado menunjukkan hasil bahwa tepat obat hanya $64,10 \%$ dan tepat dosis hanya $64,10 \%$ (Sumawa dkk, 2015).

Berdasarkan latar belakang diatas, maka penulis memandang perlu untuk diadakan penelitian yang mengevaluasi pengaruh rasionalitas penggunaan antihipertensi dengan standartguideline JNC 8 terhadap keberhasilan terapi hipertensi di RS Panti Waluyo Surakarta.

\section{Metode Penelitian}

Penelitian ini termasuk jenis penelitian cohortdimana pengambilan data dilakukan secara retrospektif dari catatan rekam medik pasien hipertensi di instalasi rawat inap di RS Panti Waluyo Surakarta selama bulan Januari sampai Desember 2016, kemudian peneliti menganalisis obat antihipertensi yang diterima pasien dengan JNC 8 dan tekanan darah ketika pasien akan pulang dengan target tekanan darah seperti yang ditetapkan oleh 
JNC 8, dimana tercapainya target tekanan darah menjadi parameter keberhasilan terapi.

\section{Subjek Penelitian}

Pasien hipertensi dengan atau tanpa penyakit penyerta (Diabetes melitus, hiperlipidemia, gagal ginjal kronik) dewasa yang berusia $\geq 18$ tahun baik laki-laki maupun perempuan, yang mendapat terapi hipertensi yang menjalani rawat inap di RS Panti Waluyo Surakarta pada periode bulan JanuariDesember 2016sebanyak 100 pasien.

\section{Instrumen Penelitian}

Form pengambilan data, digunakan untuk mengumpulkan data-data yang diambil dari buku medicalrecord atau status pasien yang meliputi nama, umur, jenis kelamin, data diagnosis rumah sakit, data-data laboratorium dan medikasi yang diterima pasien.

\section{Jalannya Penelitian}

Peneliti mencatat Data pasien hipetensi rawat inap meliputi data pasien, tanda-tanda vital pasien, data laboratorium, serta antihipertensi yang diperoleh pasien dari catatan rekam medik pasien hipertensi di instalasi rawat inap di RS Panti Waluyo Surakarta selama bulan Januari sampai Desember 2016. Setelah itu dilakukan analisis dari data yang diperoleh, yaitu : Mengidentifikasi karakteristik pasien antihipertensi di instalasi rawat inap RS Panti Waluyo Surakarta periode Januari-Desember 2016, mengidentifikasi pola pengobatan antihipertensi di instalasi rawat inap RS Panti Waluyo Surakarta periode Januari-Desember 2016 yang disajikan dalam bentuk jumlah dan persentase.

\section{Analisa Data}

Menganalisis pengaruh rasionalitas terapi hipertensi dengan guideline JNC 8 terhadap keberhasilan terapi pasien hipertensi di instalasi rawat inap RS Panti Waluyo Surakarta periode Januari-Desember 2016.

\section{Hasil dan Pembahasan}

Kasus hipertensi di RS Panti Waluyo pada tahun 2016 lebih didominasi oleh pasien berjenis kelamin perempuan yaitu sebanyak 62 pasien, dimana 23 pasien diantaranya berusia $>65$ tahun. Adapun terjadi prevalensi lebih tinggi pada perempuan bisa dikaitkan dengan proses monopouse, dapat dilihat dari hasil penelitian bahwa pada usia 46 tahun keatas pasien hipertensi lebih didominasi oleh pasien wanita daripada pasien laki- laki. Hal ini dikarenakan kadar estrogen yang terus menurun sehingga kadar High Density Lipoprotein (HDL) yang berfungsi melindungi pembuluh darah dari kerusakan juga menurun (Anggraini, 2009).

Gambaran karakteristik pasien dilihat dari ada tidaknya penyakit penyerta adalah dari 100 pasien, 70 pasien $(70 \%)$ diantaranya disertai dengan adanya penyakit penyerta dan 30 pasien (30\%) tanpa disertai dengan penyakit penyerta. Tiga jenis penyakit penyerta pada pasien hipertensi di RS Panti Waluyo Periode Januari-Desember 2016 yang paling banyak adalah strokesebesar 44,29\%, kemudian diikuti Diabetes Melitus sebesar 14,29\% dan Gastritis sebesar 11,49\%. Hipertensi merupakan faktor risiko utama terjadinya stroke (Lembo dkk, 2010). Angka kejadian stroke akan meningkat sejalan dengan peningkatan tekanan darah. Menurut JNC VII, risiko terjadinya stroke dimulai saat tekanan darah 115/75 mmHg dan akan meningkat dua kali lipat setiap peningkatan sistolik $20 \mathrm{mmHg}$ dan diastolik $10 \mathrm{mmHg}$. Tekanan darah sisitolik maupun diastolik mempunyai peran terhadap terjadinya stroke.

Data rekam medis 100 pasien hipertensi menunjukkan penggunaan jenis obat antihipertensi tunggal sebanyak 52\%, kombinasi 2 antihipertensi sebesar 43\%, dan kombinasi 3 antihipertensi5\%. Tiga golongan antihipertensi yang banyak diresepkan adalah amlodipine sebesar 34,8\%, lisinopril sebesar $20,4 \%$ dan candesartan sebesar 17,1\%. Amlodipin sangat bermanfaat mengatasi hipertensi darurat karena dosis awalnya yaitu $10 \mathrm{mg}$ dapat menurunkan tekanan darah dalam waktu 10 menit. Pasien yang diberikan amlodipine menunjukkan penurunan tekanan darah dari 150/95,7 mmHg menjadi 134/83,1 mmHg. Amlodipine merupakan obat generasi baru golongan antagonis kalsium yang memiliki selektivitas tinggi dibandingkan obat-obat sejenisnya, dan hal ini menjadi keunggulan. .ACEI menunjukkan efek positif terhadap lipid darah dan mengurangi resistensi insulin sehingga sangat baik untuk hipertensi pada diabetes, dislipidemia dan obesitas, obat ini juga sering digunakan untuk mengurangi proteinuria pada sindrom nefrotik dan nefropati DM. Selain itu ACEI juga sangat baik untuk hipertensi dengan hipertrofi ventrikel kiri, penyakit jantung koroner dan lain-lain. 
Tabel I. Hubungan Rasionalitas Terapi Hipertensi dengan GuidelineJNC 8 terhadap Keberhasilan Terapi

\begin{tabular}{ccccc}
\hline Rasionalitas & \multicolumn{2}{c}{ Keberhasilan Terapi } & Total & \multirow{2}{*}{ OR (95\%CI) } \\
\cline { 2 - 3 } & Berhasil & Tidak Berhasil & & \\
\hline Rasional & 65 & 19 & 84 & \multirow{2}{*}{3,421} \\
\hline Tidak Rasional & 8 & 8 & 16 & \\
\hline Total & 73 & 27 & 100 & \\
\hline$p$-value & & $0,031 \mathrm{p}<0,05$ & & \\
\hline
\end{tabular}

Berdasarkan tabel I dapat diketahui bahwa jika dilihat dari keberhasilan terapi, 73 pasien dari total 100 pasien mampu mencapai target tekanan darah sehingga terapi dikatakan berhasil, sedangkan 27 pasien tidak dapat mencapai target tekanan darah seperti yang ditetapkan oleh JNC 8. Hasil uji Chisquare menunjukkan bahwa ada hubungan yang signifikan antara rasionalitas terapi hipertensi dengan ketercapaian target tekanan darah pasien $(\mathrm{p}<0,05)$. Dilihat dari nilai OldRatio (OR) dapat disimpulkan bahwa kelompok pasien yang mendapat terapi hipertensi yang rasional sesuai dengan guideline JNC 8 memiliki kemungkinan mencapai target tekanan darah 3 kali lebih besar dibandingkan kelompok yang mendapat terapi hipertensi yang tidak rasional sesuai dengan guideline JNC 8, dimana hasil ini juga signifikan secara statistik $(95 \% \mathrm{CI})$.

Pemilihan antihipertensi merupakan sesuatu yang sangat kompleks, dimana terdapat banyak pilihan obat antihipertensi yang semuanya efektif untuk menurunkan tekanan darah. Tujuan utama dari terapi hipertensi adalah mencegah terjadinya komplikasi akibat hipertensi, mengurangi angka mortalitas serta morbiditas. Penurunan angka tekanan darah belum sepenuhnya dapat menjamin tidak terjadinya kerusakan organ target apabila antihipertensi yang diberikan tidak sesuai dengan kondisi pasien, seperti derajat hipertensi dan ada tidaknya compellingindication pada pasien tersebut. Pemilihan antihipertensi berdasarkan evidencebasedmedicine dan guideline terkait merupakan pilihan terbaik dalam membuat keputusan terapi yang akan diberikan pada pasien untuk mencapai tujuan akhir terapi hipertensi yaitu selain penurunan tekanan darah juga mengurangi kerusakan organ target, angka mortalitas dan morbiditas (Saseen, 2013).

\section{Simpulan}

Berdasarkan hasil penelitian dapat ditarik kesimpulan bahwa ada hubungan yang signifikan antara rasionalitas terapi hipertensi dengan ketercapaian target tekanan darah pasien $(\mathrm{p}<0,05)$. Dilihat dari nilai OldRatio (OR) dapat disimpulkan bahwa kelompok pasien yang mendapat terapi hipertensi yang rasional sesuai dengan guideline JNC
8 memiliki kemungkinan mencapai target tekanan darah 3 kali lebih besar dibandingkan kelompok yang mendapat terapi hipertensi yang tidak rasiobal sesuai dengan guideline JNC 8.

\section{Ucapan Terima Kasih}

Kami ucapkan terima kasih kepada Direktur RS Panti Waluyo beserta seluruh staf di Instalasi Farmasi dan Bagian Rekam Medik atas kesempatan yang diberikan kepada team untuk melakukan penelitian di RS Panti Waluyo.

\section{Daftar Pustaka.}

Anggraini A.D., Waren A., Situmorang E., Asputra H., Siahaan S.S., 2009, Faktor- faktor yang Berhubungan dengan Kejadian Hipertensi Pada Pasien yang berobat di Poliklinik Dewasa Puskesmas Bangkinang Periode Januari-Juni 2008, Journal Faculty of Medicine University Riau.

Damasceno, A., Azevedo, A., Silva-Matos, C., Prista, A., Diogo, D., dan Lunet, N., 2009. Hypertension prevalence, awareness, treatment, and control in mozambique: urban/rural gap during epidemiological transition. Hypertension

Lembo G dan Carvenale D., 2010, Hypertension Ana Cerebrovascular Dysfunction Acute and Chronic Brain Phatological Alteration. Jurnal High Blood Press Cardiovasc.

Saseen, J.., 2013. Essential Hypertension, dalam: Koda-Kimbleand Young's Applied Therapeutics: The Clinical Use of Drugs.

Sumawa P.M.R., Wullur A.C. dan Yamlean P.V.Y., 2015, Evaluasi Kerasionalan Penggunaan Obat Antihipertensi Pada Pasien Hipertensi Rawat Inap Di RSUP. DR. R.D. Kandou Manado Periode Januari-Juni 2014, Jurnal Ilmiah Farmasi UNSRAT Vol. 4 No. 3. 